\title{
Effect of Intense Pulsed Light on Oxidative Stress in Acne Vulgaris
}

\author{
Original Amany Matar, May EL Samahy, Samah Hassen and Nashwa EL-Khazragy \\ Article \\ Department of Dermatology and Andrology and Venereology, Faculty of Medicine, \\ Ain Shams University
}

\begin{abstract}
Background: Acne vulgaris is a multifactorial disease, studies have focused on the role of oxidative stress in the aetiopathogenesis of acne. Malondialdehyde (MDA) is a good marker of oxidative stress. Intense pulsed Light (IPL) systems are used in treatment of acne, the mechanism is reduction of Propionibacterium acnes (P. acnes) levels, decrease in the sebaceous gland function.

Objective: The study objective was to estimate the efficacy of IPL on levels of oxidative stress in acne patients taking MDA levels as an indicator before and after IPL.

Subjects and Methods: An interventional study was carried out on 20 patients with acne and 20 individuals free of acne. The severity of acne was assessed using the Global Evaluation Acne (GEA) scale. The levels of MDA were measured before the first IPL session and after 2 weeks from the last session using a spectrophotometer. Each patient received 3 IPL sessions biweekly. MDA levels in the acne free group was measured and compared to that of cases.

Results: MDA levels showed a statistically significant difference among patient after IPL treatment compared to levels before IPL treatment with the lower levels in after IPL treatment. MDA levels showed a statistically significant difference between patients and acne free individuals, with MDA being higher in patients, indicating a condition of oxidative stress that had resulted from a high level of lipid peroxidation in acne patients. As regard MDA levels, patients with moderate acne showed the higher plasma MDA levels compared with those with mild acne. The lowest MDA levels were observed in acne free individuals.

Conclusion: Serum MDA level is elevated in patients with acne than in acne free individuals. IPL can be used as a monotherapy in acne, especially in inflammatory lesions. IPL is effective in reducing oxidative stress in acne.
\end{abstract}

Key Words: Acne vulgaris; intense pulsed light; malondialdehyde; oxidative stress.

Received: 20 July 2019, Accepted: 25 July 2019

Corresponding Author: Amany Amin Matar, Dermatology and Andrology and Venereology, Faculty of Medicine, Ain Shams University, Cairo, Egypt, Tel.: +20 1007771407, E-mail: dramanymatar@hotmail.com

ISSN: 2090-7265, Journal of Recent Advances in Medicine Vol 1 issue 1 January 2020

\section{INTRODUCTION}

Acne vulgaris is a near universal inflammatory disease affecting adolescence and may continue into adulthood ${ }^{[1]}$. There are different acne lesions of various morphology, from comedones, papules, and pustules to nodules and cysts ${ }^{[2]}$. The pathogenesis of acne vulgaris is complex and multifactorial. Excess sebum production, abnormal keratinization of the follicles, P. acnes colonization, and inflammation of the follicle and surrounding dermis are considered the major factors involved in the pathogenesis of acne ${ }^{[3]}$.

Studies on the aetiopathogenesis of acne vulgaris have focused on the role of oxidative stress ${ }^{[4-6]}$. Excess Reactive oxygen species (ROS) production leads to a condition known as oxidative stress ${ }^{[7-9]}$. Oxygen free radicals, which are generated by the neutrophils on the follicular wall, may cause cell damage at the site of inflammation ${ }^{[10-14]}$. Sebum production is increased in acne vulgaris ${ }^{[15]}$. MDA is the end product of lipid peroxidation. MDA is a good marker of free radicalmediated damage and oxidative stress ${ }^{[16-19]}$.
With technological advancement, light and laser therapy with better efficacy and safety can be used as an ideal treatment not only adjunctively, but also alternatively. IPL is an incoherent high intensity pulsed light with wide range of wavelength targeting various chromophores in the skin. IPL devices employ polychromatic light. Part of the light is reflected, absorbed or penetrates the skin. When light hits the skin, skin-light interaction occurs. The absorbed light interacts with biomolecules and elicits various biological responses. Light penetration depth varies according to wavelength. The absorption of light by endogenous chromophores in the skin create enough heat and energy to target the blood vessels that supply sebaceous glands in order to reduce sebum production. This absorption of light also leads to the generation of ROS with subsequent bactericidal effects. Inactivation of P.acnes and photothermal effect in pilosebaceous unit are believed to be the main targets of this biological reaction $^{[20]}$. Current studies using IPL as an anti acne therapy did not show whether the IPL can affect the 
oxidative stress in acne vulgaris or not.

The aim of this work was to estimate the efficacy of IPL treatment on levels of oxidative stress in acne vulgaris patients by estimating serum MDA level before and after treatment compared to acne free individuals.

\section{SUBJECTS AND METHODS}

An interventional study was carried out on 20 patients with mild to moderate acne vulgaris and also 20 healthy subjects free of acne vulgaris were included. Patients were selected randomly from the Dermatology and Venereology outpatient clinic, faculty of medicine, Ain-Shams University Hospitals in the period from December 2018 to April 2019. The study was approved by the Research Ethical Committee of Ain Shams University and fulfilled all the ethical aspects required in human research. Acne free subjects were selected age and sex matched healthy volunteers from undergraduate students, faculty of medicine, Ain-Shams University. A written informed consent was obtained from all study subjects.

\section{Exclusion criteria for patients}

Patients with the following criteria were excluded from the study: patients less than 15 and above 30 years old, pregnant patients, lactating patients, patients with a history of photosensitivity, patients with nodulocystic acne, patients with history of topical acne treatment within the last 2 weeks, patients with history of the use of systemic retinoids within the last 6 months, patients with extra-facial acne and acneiform eruptions, patients with concomitant dermatological disease other than acne vulgaris, chronic systemic diseases such as chronic renal failure, hepatic insufficiency, cardiovascular disorders, diabetes mellitus, thyroid disorders, anemia and malignancy because free radicals are likely to be elevated in these cases, the use of topical or systemic treatment affecting any free radical scavenging such as vitamins, antibiotics, and anti-inflammatory drugs for 1 month before starting IPL sessions, smoking and alcohol abuse as both can induce oxidative stress, and recent history of psychiatric disorders.

All patients were subjected to complete assessment of history on the onset, duration, and the course of the lesions. Type of lesions, their number, and their distribution were recorded. The severity of the disease in every patient was assessed using the Global Evaluation Acne (GEA) scale ${ }^{[22]}$. The serum MDA level was measured before the first IPL session and after two weeks from the last IPL session. Principle of the malondialdehyde colorimetric assay Thiobarbituric acid reacts with MDA in an acidic medium at a temperature of $95^{\circ} \mathrm{C}$ for $30 \mathrm{~min}$ to form a thiobarbituric acid reactive product. The absorbance of the resultant pink product can be measured at $534 \mathrm{~nm}$ using a spectrophotometer. The results were expressed as $\mu \mathrm{mol} / 1$. Each patient received three IPL sessions as a monotherapy with 2 weeks interval. All patient were photographed at baseline, before each session and two weeks after the last session. Comedonal extraction was done for all patients before starting treatment sessions. Two subsequent passes were used at each treatment session using $430 \mathrm{~nm}$ and $640 \mathrm{~nm}$ cut off filters. 430 $\mathrm{nm}$ cut off filter was used in the first pass, triple pulse mode, pulse width $7 \mathrm{~ms}$, delay time $20 \mathrm{~ms}$, fluence of $79-\mathrm{J} / \mathrm{cm} 2.640 \mathrm{~nm}$ cut off filter was used in the second pass, triple pulse mode, with pulse width $8 \mathrm{~ms}$ and delay time $20 \mathrm{~ms}$, fluence of $20 \mathrm{~J} / \mathrm{cm} 2$. Serum MDA level was measured for acne free individuals.

\section{Statistical analysis}

Data were collected, revised, coded and entered to the Statistical Package for Social Science (IBM SPSS) version 23 . The quantitative data were presented as mean, standard deviations and ranges when parametric while non-parametric were presented as median with inter-quartile range (IQR). Also qualitative variables were presented as number and percentages. The comparison between two independent groups with quantitative data and non-parametric distribution was done by using Mann-Whitney test. The confidence interval was set to $95 \%$ and the margin of error accepted was set to $5 \%$.

\section{RESULTS}

\section{Demographic data}

The present study included 20 patients with acne vulgaris: 4 males and 16 females representing $80 \%$ of total number of cases, with a mean age of $20 \pm$ 3.35 years. Negative family history predominance, 15 cases out of 20 cases, was found representing $75 \%$ of total number of cases. Patients were graded according to GEA as follows: mild (17 patients) and moderate (3 patients) (Table 1$)$.

Table 1: Description of personal characteristics among cases group.

\begin{tabular}{cccc}
\hline \multicolumn{2}{c}{ Characteristic } & No. & $\%$ \\
\hline \multirow{4}{*}{ Sex } & Male & 4 & $20.0 \%$ \\
& Female & 16 & $80.0 \%$ \\
Occupation & Student & 17 & $85.0 \%$ \\
& Doctor & 2 & $10.0 \%$ \\
Family history & Housewife & 1 & $5.0 \%$ \\
& Positive & 5 & $25.0 \%$ \\
Age years: & Negative & 15 & $75.0 \%$ \\
& & Mean \pm SD & Range \\
& & $20 \pm 3.35$ & $16-28$ \\
\hline
\end{tabular}

Table 2 shows that there is a statistically significant difference between serum MDA level in acne cases before IPL and MDA levels in acne free individuals with high results in acne cases. 
Table 2: Comparison between acne cases and acne free group as regard MDA level

\begin{tabular}{|c|c|c|c|c|c|c|c|c|}
\hline & \multicolumn{3}{|c|}{ Acne cases before IPL } & \multicolumn{3}{|c|}{ Acne free group } & \multirow{2}{*}{$P$} & \multirow{2}{*}{ Sig } \\
\hline & Median & & & Median & & $\mathrm{R}$ & & \\
\hline \multirow[t]{2}{*}{$\begin{array}{l}\text { MDA } \\
\text { before }\end{array}$} & 110.00 & 84.15 & 123.25 & 36.60 & 32.40 & 38.30 & 0.001 & S \\
\hline & *Mann- & iitne & est & & 0.05 & Signi & ant & \\
\hline
\end{tabular}

Table 3 shows that there was a statistically significant difference between MDA before and after IPL treatment among acne cases, with lower values after IPL.

Table 3: Comparison between Serum MDA before and after IPL among study cases

\begin{tabular}{ccccc}
\hline & Median & IQR & P & Sig \\
\hline MDA before & 110 & $84.1-123.2$ & 0.001 & $\mathrm{~S}$ \\
MDA after & 45.4 & $35.6-75.3$ & & \\
\hline
\end{tabular}

Table 4 shows that $85 \%$ of acne cases had mild acne grade while $15 \%$ had moderate acne grade before IPL. After IPL, $85 \%$ of cases almost clear lesions while $15 \%$ had mild acne grade. Previous treatment was reported by $20 \%$ of cases only. Transient erythema was present in $100 \%$ of acne cases. As regard satisfaction, all acne cases were satisfied.

Table 4: Description of disease characteristics among cases group

\begin{tabular}{lcc}
\hline Characteristic & No. $(\mathrm{TN}=20)$ & $\%$ \\
\hline Acne Grading before IPL: & 17 & $85.0 \%$ \\
Mild & 3 & $15.0 \%$ \\
Moderate & & \\
Acne Grading after IPL: & 17 & $85.0 \%$ \\
Almost clear & 3 & $15.0 \%$ \\
Mild & & \\
Previous treatment: & 4 & $20.0 \%$ \\
Yes & 16 & $80.0 \%$ \\
No & & \\
Type of previous treatment & 16 & $80.0 \%$ \\
No Treatment & 3 & $15.0 \%$ \\
Topical only & 1 & $5.0 \%$ \\
Topical and systemic & & \\
Side effects of IPL: & 20 & $100.0 \%$ \\
Transient erythema & 20 & $100.0 \%$ \\
Patient satisfaction after IPL & & \\
\hline
\end{tabular}

\section{DISCUSSION}

This study was a pilot study included 20 patients and 20 acne free individuals with age and sex matched.

The present study assessed the efficacy of intense pulsed light as a monotherapy on levels of oxidative stress in acne vulgaris patients taking serum Malondialdehyde levels as an indicator before and after the treatment protocol compared with acne free individuals, over a period of four months.

The present study included two groups: cases group, 20 patients with mild and moderate acne vulgaris, treated by IPL and 20 healthy persons who served as control group.

In the present study, we found that acne cases had significantly higher levels of serum MDA than the acne free individuals. This is in agreement with Arican et $a{ }^{\left[{ }^{[17]}\right.}$ and Sarici et al..$^{[23]}$, who suggested that this increase indicates the high levels of lipid peroxidation because of exposure to ROS. On the opposite side, Basak et al. ${ }^{[18]}$ found insignificantly higher levels in the patient group, their results were based on the fact that the enzymatic antioxidant system was not completely inhibited.

The present study showed increase serum MDA levels observed in patients with moderate acne than mild acne. In patients with moderate acne, MDA levels were significantly increased, indicating an increase in ROS production overwhelming the antioxidant capacity. With increased severity of the disease process, the protective mechanism becomes inadequate, with increased production of ROS leading to initiation of the lipid peroxidation chain reaction, leading to peroxidation of membrane lipids and other tissue lipids. Our results are in agreement with those of Abdel Fattah et al. ${ }^{[21]}$, who assessed the oxidant - antioxidant system in patients with acne vulgaris with different acne severity grades. This explains our results of MDA level that was the lowest in acne free individuals and explains that decrease in the MDA level after IPL therapy was due to decrease the ROS and decrease oxidative stress in the study cases.

Arican et al. ${ }^{[17]}$, Basak et al. ${ }^{[18]}$, and Kurutas et $a l .{ }^{[19]}$ could not detect any correlation between the severity of acne and the levels of serum MDA. According to them, oxidant - antioxidant balance may be affected to a specific extent in every patient. AlShobaili et al. ${ }^{[24]}$ suggested that MDA which is a marker of oxidative stress might be useful in evaluating the pathogenesis and the progression of acne.

In the present study each patient underwent 3 IPL sessions two weeks apart. The detection of serum MDA levels before and after IPL sessions reported a highly significant reduction among all study cases after two weeks from the third IPL session compared with pretreatment levels, with lower values after IPL treatment.

The protocol for applying IPL in treatment of acne vulgaris is variable with no recommended guidelines. Differences in the results may be related to different fluences, no of sessions and the used cut off filters.

In the present study, all patients were satisfied. 
No recorded hyperpigmentation, blister formation or scarring following IPL treatment protocol. The treatment clinical endpoint was slight immediate transient erythema of the skin and pain during the session was noted in $100 \%$ of cases, they were very trivial and tolerable, there were no severe adverse events and hence, all patients completed the study successfully. There were no long-term adverse events.

Following our patients up to 2 months revealed that the beneficial effect of IPL was maintained after the last session. In the present study, we discovered that our IPL treatment protocol has both immediate therapeutic effect during the treatment course and prolonged effect after stopping the treatment sessions. Our explanation was that this may be related to partly according to the present results, to the decreased oxidative stress that may underlie the antibacterial or anti-inflammatory effect.

According to the present results, oxidative stress is considered to have a role in aetiopathogenesis of acne vulgaris. The antioxidant defense system is particularly damaged in cases of high grade acne. IPL can be used as a monotherapy in treatment of inflammatory mild to moderate acne vulgaris. IPL is effective in reducing oxidative stress in acne vulgaris.

\section{CONFLICTS OF INTEREST}

There ar no Conflicts of Interest

\section{REFERENCES}

1. Collier CN, Harper JC, Cantrell WC, Wang W, Foster KW, Elewski BE. The prevalence of acne in adults 20 years and older. J Am Acad Dermatol 2008; 58:56-59.

2. Amin K, Riddle C, Aires D, Schweiger E. Common and alternate oral antibiotic therapies for acne vulgaris: a review. J Drugs Dermatol 2007; 6:873-880.

3. Clarke SB, Nelson AM, George RE, Thiboutot DM. Pharmacologic modulation of sebaceous gland activity: mechanisms and clinical applications. Dermatol Clin 2007; 25:137-146.

4. Babior BM. Phagocytes and oxidative stress. J Am Med 2000; 109:33-44.

5. Bickers DR, Athar M. Oxidative stress in the pathogenesis of skin disease. J Invest Dermatol 2006; 126:2565-2575.

6. Okayama Y. Oxidative stress in allergic and inflammatory skin diseases. Curr Drug Targets Inflamm Allergy 2005; 4:517-519.

7. Briganti S, Picardo M. Antioxidant activity, lipid peroxidation and skin diseases. What's new? J Eur Acad Dermatol Venereol 2003; 17:663-669.
8. Oztas MO, Balk M, Ogu“s E, Bozkurt M, Ogu“s IH, Ozer N. The role of free oxygen radicals in the aetiopathogenesis of rosacea. Clin Exp Dermatol. 2003; 28:188-192.

9. Cornobare MD. Skin photosensitizing agents and the role of reactive species in photoaging. J Photochem Photobiol B 1992; 14:105-124.

10. Zouboulis CC, Eady A, Philpott M, Goldsmith LA, Orfanos C, Cunliffe WC, et al. What is the pathogenesis of acne? Exp Dermatol 2005; 14:143-152.

11. Auffret N. What's new concerning the pathophysiology of acne? Ann Dermatol Venereol 2003; 130:101-106.

12. Koreck A, Pivarcsi A, Dobozy A, Keme'ny L. The role of innate immunity in the pathogenesis of acne. Dermatology 2003; 206:96-100.

13. Kligman AM. An overview of acne. J Invest Dermatol 1974; 62:268-287.

14. Akamatsu H, Horio $\mathrm{T}$, Hattori K. Increased hydrogen peroxide generation by neutrophils from patients with acne inflammation. Int $\mathrm{J}$ Dermatol 2003; 42:366-369

15. Bowe WP, Patel N, Logan AC. Acne vulgaris: the role of oxidative stress and the potential therapeutic value of local and systemic antioxidants. J Drugs Dermatol 2012; 11:742-746.

16. Koca R, Armutcu F, Altinyazar HC, Gürel A. Oxidant-antioxidant enzymes and lipid peroxidation in generalized vitiligo. Clin Exp Dermatol 2004; 29:406-409.

17. Arican O, Kurutas EB, Sasmaz S. Oxidative stress in patients with acne vulgaris. Mediators Inflamm 2005; 6:380-384.

18. Basak PY, Gultekin F, Kilinc I. The role of the antioxidative defense system in papulopustular acne. J Dermatol 2001; 28:123-127.

19. Kurutas EB, Arican O, Sasmaz S. Superoxide dismutase and myeloperoxidase activities in polymorphonuclear leukocytes in acne vulgaris. Acta Dermatovenereol Alp Panonica Adriat 2005; 14:39-42.A

20. Deshpande A J. Efficacy and Safety Evaluation of High density Intense Pulsed Light in the Treatment of Grades II and IV Acne Vulgaris as Monotherapy in dark-skinned women of child bearing age. J Clin Aesthet Dermatol.11.2018; (4): $43-48$.

21. Abdel Fattah NS, Shaheen MA, Ebrahim AA, El Okda ES. Tissue and blood superoxide dismutase activities and malondialdehyde levels in different clinical severities of acne vulgaris. Br J Dermatol 2008; 159:1086-1091. 
22. Dréno B, Poli F, Pawin H, et al. Development and evaluation of a Global Acne Severity Scale (GEA Scale) suitable for France and Europe. J. Eur. Acad. Dermatol. Venereol. 2011;25: 43- 48.

23. Sarici G, Cinar S, Armutcu F, Altınyazar C, Koca R, Tekin NS. Oxidative stress in acne vulgaris. J Eur Acad Dermatol Venereol 2010 24:763-767.

24. Al-Shobaili HA, Alzolibani AA, Al RobaeeAA, Meki AR, Rasheed Zl. Biochemical markers of oxidative and nitrosative stress in acne vulgaris correlation with disease activity. J Clin Lab Anal 2013; 27:45-52. 


\section{الملخص العربى}

\section{تأثير الضوء النبضي المكثف على الإجهاد التأكسدي في حب الشباب}

\section{أمساني أمين مطر '، مسيّ حسين السماحي'، سماح إبراهيم حس'، نشوى ناجي الخزرجي'}

'قسم الامر اض الجلديه الجلدية والتناسلية وأمر اض الأكورة ـ كلية الطب - جامعة عين شمس

ثقمم الباثولوجيا الاكلينيكية وأمراض الام ـ كلية الطب - جامعة عين شمس

المقدمه: حب الثباب هو مرض متعدد الأسباب، و قد ركزت الدر اسات على دور الاجهاد التاكسدي المكثف في حدوث حب الثباب ويعتبر قياس مستوى المالونديالدهيد في الدم مقياس لمستوى الاجهاد التاكسدي، ويستخدم الضوء النبضى المكثف في علاج حب الشباب حيث يعمل على تقليل مستويات بكتيريا حب الثباب وخفض وظائف الغدد الدهنيه. الهدف من هذه الاراسه: هو تقيبم مدى تأثير الضوء النبضي المكثف على مستوى الاجهاد التاكسدى في مرضى حب الثباب عن طريق قياس مستويات المالونديالدهيد في الدم قبل وبعد الجلسات. حالات الاراسد: الدر اسه الحاليه هي دراسه تداخليه وتم تنفيذ هذه الدراسه على • r من المرضي الذسن بعانون من مرض حب الثباب و • ب فرد من الاصحاء، و تم قياس مستويات المالونديالدهيد في الدم قبل اول جلسه و بعد اسبو عين من اخر جلسه، تلقى كل مريض r جلسات من الضوء النبضي المكثف بفاصل زمني اسبو عين بين الجلسات وتم ايضا قياس قياس مستويات المالونديالدهيد في الام في الاصحاء. النتائج: كثنف نتائج الدر اسه فرقا عاليا يعتد به احصائيا بين الحالات قبل وبعد الجلسات حيث كانت القيم المنخفضه بعد الجلسات و ايضا فرقا عاليا يعتد به احصائيا بين الحالات والاصحاء حيث كانت القيم المرتفعه بين المرضى ويدل ذلك على ارتفاع مستويات الاجهاد التاكسدي نتيجة لبيروكسيد الدهون في حب الشباب، وسجلت مستويات المالونديالدهيد في الدم ارتفاعا ملحوظا في حالات حب الثباب من الدرجه المتوسطه عن مستويات الدرجه البسيطه، وسجلت مستويات المالونديالدهيد في الدم بين الاصحاء اقل المستويات في الدر اسه. الاستنتاجات: مستويات المالونديالدهيد في الدم فى مرضى حب الثباب اعلى من مستويات المالونديالدهيد في الدم بين الاصحاء، يستخدم تأثثر الضوء النبضي المكثف كعلاج احادي في حالات حب الثباب وخاصا في حالات الالتهاب، يستخدم العلاج بالضوء النبضي المكثف لنقليل مستويات الاجهاد التاكسدي في حب الثباب. 